\title{
Study of Brain Electrolytes and Organic Osmolytes during Correction of Chronic Hyponatremia Implications for the Pathogenesis of Central Pontine Myelinolysis
}

Yeong-Hau H. Lien, Joseph I. Shapiro, and Laurence Chan

Department of Medicine, University of Colorado Health Sciences Center, Denver, Colorado 80262

\begin{abstract}
Osmotic injury induced by rapid correction of severe chronic hyponatremia has been implicated in the development of central pontine myelinolysis. Organic osmolytes known previously as "idiogenic osmoles" accumulate intracellularly to protect cells from osmotic injury. We investigated the changes of these organic osmolytes as well as electrolytes in the brain during the induction and correction of chronic hyponatremia. Using ${ }^{1} \mathbf{H}$ nuclear magnetic resonance spectroscopy and HPLC, we found that in rats with chronic hyponatremia ( $3 \mathrm{~d}$, serum sodium $=$ $109 \pm 3$ meq/liter), brain concentrations of myoinositol (41\%), glycerophosphorylcholine (45\%), phosphocreatine/creatine $(60 \%)$, glutamate $(53 \%)$, glutamine $(45 \%)$, and taurine $(37 \%)$ were all significantly decreased compared with control values (percentage control value shown, all $P<0.01$ ). The contribution of measured organic osmolytes and electrolytes to the total brain osmolality change was 23 and $72 \%$, respectively. With rapid correction by $5 \% \mathrm{NaCl}$ infusion, significant brain dehydration and elevation of brain $\mathrm{Na}$ and $\mathrm{Cl}$ levels above the normal range occurred at $24 \mathrm{~h}$. These changes were not seen with slow correction by water deprivation. Reaccumulation of most organic osmolytes except glycerophosphorylcholine is delayed during the correction of hyponatremia and is independent of the correction rate of serum sodium. It is concluded that: most of the change of brain osmolality in chronic hyponatremia can be accounted by the changes in organic osmolytes and brain electrolytes; and rapid correction of hyponatremia is associated with an overshoot of brain sodium and chloride levels along with a low organic osmolyte level. The high cerebral ion concentrations in the absence of adequate concentrations of organic osmolytes may be relevant to the development of central pontine myelinolysis. (J. Clin. Invest. 1991. 88:303-309.) Key words: idiogenic osmoles $\bullet$ myoinositol $\bullet$ glycerophosphorylcholine - nuclear magnetic resonance - high performance liquid chromatography
\end{abstract}

\section{Introduction}

Organic osmolytes play an important role in the cellular adaptation to osmolality changes. They accumulate intracellularly to

Address correspondence and reprint requests to Dr. Yeong-Hau H. Lien, Section of Renal Disease, Department of Medicine, University of Arizona Health Sciences Center, Tucson, AZ 85724.

Received for publication 5 December 1990 and in revised form 23 February 1991.

J. Clin. Invest.

(c) The American Society for Clinical Investigation, Inc.

0021-9738/91/07/0303/07 \$2.00

Volume 88, July 1991, 303-309 maintain cell volume and cellular functions when extracellular osmolality increases $(1,2)$. It is well known that amino acids such as taurine, glutamate, and glutamine accumulate in the brain of experimental animals with chronic hypernatremia (35). More recently, we and others have demonstrated that myoinositol, glycerophosphorylcholine (GPC), ${ }^{1}$ and phosphocreatine (PCr)/creatine ( $\mathrm{Cr}$ ) are also important organic osmolytes (6-9). It is estimated that the increase of these measured organic osmolytes and brain electrolytes can account for virtually all of the observed increase in brain osmolality during hypernatremic states. The term "idiogenic" to describe these organic osmolytes is probably outdated (6).

Central pontine myelinolysis, first described by Adams and his associates (10), is characterized by a loss of oligodendrocytes and myelin with relatively well reserved neuronal cell body and axons in central basis pontis as well as extra-pontine sites such as basal ganglia, internal capsule, and cerebellum $(11,12)$. Clinical studies have suggested that rapid correction of hyponatremia, especially a large magnitude of correction (greater than $25 \mathrm{meq} / \mathrm{liter}$ in first 24-48 h), may be associated with this neurological lesion $(13,14)$. Animal studies have definitively shown that symmetrical demyelinating lesions of the central nervous system occur after hypertonic infusion for correction of severe chronic hyponatremia (15-18). Slow correction of hyponatremia, however, does not appear to be associated with this neurological lesion either clinically or experimentally (13-17).

It has been postulated that organic osmolytes may play some role in the pathogenesis of central pontine myelinolysis because the accumulation of organic osmolytes would be expected to be outpaced by the rise of osmolarity during the rapid correction of hyponatremia. Thurston and others have previously shown that the brain content of some of these organic osmolytes does not normalize at $9 \mathrm{~h}$ after the correction of hyponatremia with hypertonic saline infusion $(9,19)$. In this paper, we have investigated the time course of the changes of brain water, electrolytes, and the concentrations of the major organic compounds believed to be important organic osmolytes in rats during rapid or slow correction of chronic hyponatremia.

\section{Methods}

Animal models. Male Sprague-Dawley rats weighing 300-350 g were used. Hyponatremia was induced with the methods described by Verbalis and Drutarosky (20). In brief, rats were treated with minipump (Alzet 2002; Alza Co., Palo Alto, CA) infusion of DDAVP (1-des-

1. Abbreviations used in this paper: $\mathrm{Cr}$, creatine; GPC, glycerophosphorylcholine; NMR, nuclear magnetic resonance; $\mathrm{PCr}$, phospho-Cr; TSP, trimethylsilylproprionate. 
amino-8-D-arginine vasopressin, $4 \mu \mathrm{g} / \mathrm{ml}$; Rorer Pharmaceutical Co., Fort Washington, PA) along with feeding of $40 \mathrm{ml}$ liquid diet (AIN76A; Dyets, Inc., Bethlehem, PA) per day for $3 \mathrm{~d}$. Control rats received the same diet without DDAVP infusion. Rapid correction was accomplished by a single intraperitoneal injection of $5 \%$ saline $2.5 \mathrm{ml} / 100 \mathrm{~g}$ body weight. Slow correction was accomplished by water deprivation. The liquid diet was discontinued and rats were allowed ad libitum normal chow (Wayne Lab Blox; Ralstron-Purina Co., St. Louis, MO). Daily weight and series of serum $\mathrm{Na}, \mathrm{K}, \mathrm{Cl}$, osmolarity, and urea nitrogen were determined. Once serum sodium level reached the normal range, rats were allowed to drink water ad lib. On day 1,2 , and 7 after initiation of treatment, rats were decapitated and brains were used for measurement of brain water, electrolytes, and organic osmolytes.

Brain water and electrolyte content. Total brain water content was measured by weighing before and after desiccation $\left(16 \mathrm{~h}\right.$ at $\left.100^{\circ} \mathrm{C}\right)$. The dried residue was subsequently digested with concentrated nitric acid for $48 \mathrm{~h}$ for $\mathrm{Na}$ and $\mathrm{K}$ measurement using an atomic absorption spectrophotometer (Perkin-Elmer Co., Norwalk, CT) or with $0.75 \mathrm{~N}$ $\mathrm{HNO}_{3}$ for $72 \mathrm{~h}$ for chloride $(\mathrm{Cl})$ measurement using a chloridometer (Haake-Buchler Instruments, Frankfort, Germany) as described previously $(20,21)$.

Nuclear magnetic resonance (NMR) spectroscopy. Whole brains were extracted with perchloric acid, then neutralized, lyophilized, and reconstituted in $\mathrm{D}_{2} \mathrm{O}$ "spiked" with the sodium salt of trimethylsilylproprionate (TSP; Sigma Chemical Co., St. Louis, MO) as an internal chemical shift and concentration standard $(6,7) .{ }^{1} \mathrm{H}-\mathrm{NMR}$ spectroscopy was performed using a $7.05 \mathrm{Tesla}, 10$-cm vertical-bore cryomagnet, AM-300 spectrometer, and commercial 5-mm probe (Bruker Instruments, Inc., Billerica, MA). ${ }^{1} \mathrm{H}-\mathrm{NMR}$ spectra were obtained at 300 $\mathrm{MHz}$ using a sweep width of $10 \mathrm{ppm}$ and 16,000 data arrays. 128 transients were collected with 90 degree pulses applied every $10 \mathrm{~s}$ and summed. The free induction decay was Fourier transformed without further manipulation. All spectra were baseline corrected before peak integration. The integral of each peak was analyzed relative to the integral of the TSP peak and converted into a chemical concentration, as described by Gullans and co-workers (7) and reported previously by our group (6).

High performance liquid chromatography. HPLC was performed using a Sugar-Pak 1 column (Waters Associates, Milford, MA) as described by Wolff and others (22). An aliquot of $50 \mu \mathrm{l}$ of brain extract was injected and eluted with $0.1 \mathrm{mM}$ calcium disodium EDTA at 0.5 $\mathrm{ml} / \mathrm{min}$ and $80^{\circ} \mathrm{C}$. Metabolites were detected with a refractive index detector (Altex Scientific, Inc., Berkeley, CA) and analyzed as described previously (6).

Statistics. One way analysis of variance was performed to demonstrate differences among group means. Comparison of group means with the control was done using Student's $t$ test for unpaired data employing Scheffe's method to correct for multiple comparisons (23). Significance levels are reported at the $P<0.05$ and $P<0.01$ levels.

\section{Results}

\section{Effects of chronic hyponatremia}

Physiologic measurements. All rats survived the induction of hyponatremia without significant symptoms. Table I shows the body weight changes during the induction of hyponatremia. There was a small but significant weight gain 1 and $2 \mathrm{~d}$ after implantation of the minipump. This weight gain is due to positive water balance as demonstrated by Verbalis and Drutarosky in their initial description of this hyponatremic rat model (20). Table II summarizes the serum concentrations of electrolytes, urea nitrogen, and osmolality after induction of chronic hyponatremia. In rats with chronic hyponatremia, serum $\mathrm{Na}$ ( $109 \pm 3$ vs. $142 \pm 2 \mathrm{meq} / \mathrm{liter}), \mathrm{Cl}(68 \pm 2$ vs. $102 \pm 2 \mathrm{meq} / \mathrm{liter})$, and osmolality ( $237 \pm 8$ vs. $302 \pm 2 \mathrm{mosmol} / \mathrm{kg}$ ) decreased signifi-
Table I. Weight Changes during the Induction of Hyponatremia

\begin{tabular}{lclcc}
\hline \multicolumn{1}{c}{ Day } & \multicolumn{1}{c}{0} & \multicolumn{1}{c}{1} & \multicolumn{1}{c}{2} & \multicolumn{1}{c}{3} \\
\hline Rat groups $(n)$ & & & & \\
Control (6) & $318 \pm 8$ & $316 \pm 9$ & $316 \pm 10$ & $320 \pm 8$ \\
Hyponatremia (6) & $315 \pm 9$ & $322 \pm 10^{*}$ & $320 \pm 9^{*}$ & $317 \pm 10$ \\
\hline
\end{tabular}

Day 0 indicates the day of minipump placement. $n$, number of rats in each group. Values are mean \pm SD. ${ }^{*} P<0.05$ vs. day 0 using paired Student's $t$ test.

cantly compared with control rats (all $P<0.01)$. Serum $\mathrm{K}$ and urea nitrogen levels were not changed in hyponatremic rats.

Brain water and electrolytes. Table III summarizes the effects of chronic hyponatremia on brain water content and brain electrolyte concentrations. Brain water content was not significantly different between chronically hyponatremic $(79.0 \pm 0.4 \%)$ and control $(78.6 \pm 0.2 \%)$ rats. Brain $\mathrm{Na}(44 \pm 2$ vs. $\left.56 \pm 2 \mathrm{meq} / \mathrm{kg} \mathrm{H}_{2} \mathrm{O}\right), \mathrm{K}\left(97 \pm 3\right.$ vs. $\left.121 \pm 4 \mathrm{meq} / \mathrm{kg} \mathrm{H}_{2} \mathrm{O}\right)$, and $\mathrm{Cl}$ $\left(30 \pm 3\right.$ vs. $\left.42 \pm 2 \mathrm{meq} / \mathrm{kg} \mathrm{H}_{2} \mathrm{O}\right)$ in hyponatremic rats decreased significantly compared with controls (all $P<0.01$ ).

Brain organic osmolytes. Organic osmolytes were measured with NMR spectroscopy and HPLC. Previous studies from our laboratory have shown that HPLC with a Sugar-Pak 1 column can be used to quantitate myoinositol, GPC, taurine, glutamine, and urea in brain extract. ${ }^{1} \mathrm{H}-\mathrm{NMR}$ can be used to measure all of these organic osmolytes except urea. Table IV summarizes the concentrations of individual osmolytes measured with ${ }^{1} \mathrm{H}-\mathrm{NMR}$ spectroscopy and HPLC. All measured organic osmolytes decreased significantly in hyponatremic rats compared with controls. NMR study showed that the concentration of myoinositol in the brain of hyponatremic rats decreased from $5.1 \pm 0.4$ to $2.1 \pm 0.6 \mathrm{mmol} / \mathrm{kg} \mathrm{H} \mathrm{H}_{2} \mathrm{O}$; GPC from $1.1 \pm 0.2$ to $0.5 \pm 0.1 \mathrm{mmol} / \mathrm{kg} \mathrm{H} \mathrm{H}_{2} \mathrm{O} ; \mathrm{PCr} / \mathrm{Cr}$ from $3.5 \pm 0.2$ to $2.1 \pm 0.3 \mathrm{mmol} / \mathrm{kg} \mathrm{H} \mathrm{H}_{2} \mathrm{O}$; glutamate from $11.6 \pm 1.0$ to $6.1 \pm 0.9$ $\mathrm{mmol} / \mathrm{kg} \mathrm{H}_{2} \mathrm{O}$; glutamine from $4.0 \pm 0.3$ to $1.8 \pm 0.6 \mathrm{mmol} / \mathrm{kg}$ $\mathrm{H}_{2} \mathrm{O}$; and taurine from $3.5 \pm 0.4$ to $1.3 \pm 0.4 \mathrm{mmol} / \mathrm{kg} \mathrm{H}_{2} \mathrm{O}$ (all $P$ $<0.01)$. The results obtained from HPLC were extremely consistent with those from NMR spectroscopy. The brain urea concentration in hyponatremic rats was not significantly different from that in the control $(3.4 \pm 0.3$ vs. $4.1 \pm 0.6 \mathrm{mmol} / \mathrm{kg}$ $\mathrm{H}_{2} \mathrm{O}, P=\mathrm{NS}$ ).

Fig. 1 demonstrates the contribution of the change of each molecule measured to the total change of osmolality in hyponatremia assuming that all electrolytes and organic osmolytes

Table II. Serum Electrolytes, Urea Nitrogen, and Osmolarity

\begin{tabular}{lcc}
\hline & \multicolumn{2}{c}{ Rat group $(n)$} \\
\cline { 2 - 3 } & Control (6) & Hyponatremia (6) \\
\hline Serum Na (meq/liter) & $142 \pm 2$ & $109 \pm 3^{*}$ \\
Serum K (meq/liter) & $3.8 \pm 0.4$ & $3.7 \pm 0.2$ \\
Serum Cl (meq/liter) & $102 \pm 2$ & $68 \pm 2^{*}$ \\
Serum urea nitrogen (mg/dl) & $5 \pm 1$ & $5 \pm 1$ \\
Serum osmolality (mosmol/kg) & $302 \pm 2$ & $237 \pm 8^{*}$ \\
& & \\
\hline
\end{tabular}

$n$, Number of rats in each group. Values are mean \pm SD.

${ }^{*} P<0.01$ vs. control rats. 
Table III. Brain Water and Electrolyte Content

\begin{tabular}{lcc}
\hline & \multicolumn{2}{c}{ Rat group (n) } \\
\cline { 2 - 3 } & Control (6) & Hyponatremia (6) \\
\hline Brain water content (\%) & $78.6 \pm 0.2$ & $79.0 \pm 0.4$ \\
Brain $\mathrm{Na}\left(\mathrm{meq} / \mathrm{kg} \mathrm{H} \mathrm{H}_{2} \mathrm{O}\right)$ & $56 \pm 2$ & $44 \pm 2^{*}$ \\
Brain $\mathrm{Cl}\left(\mathrm{meq} / \mathrm{kg} \mathrm{H}_{2} \mathrm{O}\right)$ & $42 \pm 2$ & $30 \pm 3^{*}$ \\
Brain K (meq/kg $\left.\mathrm{H}_{2} \mathrm{O}\right)$ & $121 \pm 4$ & $97 \pm 3^{*}$
\end{tabular}

$n$, Number of rats in each group. Values are mean \pm SD.

$* P<0.01$ vs. control rats.

are osmotically active, thus, the osmotic activity coefficient of each individual molecule is close to one. The decrease of brain electrolytes accounted for $72 \%$ of the observed osmolality change. Specifically, changes in tissue $\mathrm{Na}$ contributed $18 \%$, changes in tissue $\mathrm{Cl} 18 \%$, and changes in tissue $\mathrm{K} 36 \%$ of the change. The contribution of the measured organic osmolytes to the total osmolality change was $23 \%$. Specifically, changes in the tissue concentrations of amino acids contributed $15 \%$, changes in tissue myoinositol $5 \%$, and changes in tissue concentrations of GPC and $\mathrm{PCr} / \mathrm{Cr} 3 \%$. Altogether, $95 \%$ of the observed change in brain tissue osmolality was accounted for by the changes in tissue concentrations of these measured electrolytes and organic osmolytes.

\section{Effect of correction of hyponatremia}

Physiologic measurements. Chronic hyponatremia was corrected either rapidly with hypertonic saline injection or slowly with dehydration. Among those rats that were allowed to live to day 7 after initiation of treatment, 4 rats out of 10 died after rapid correction: 2 on day 3,1 on day 4, and 1 on day 5; only 1 rat out of 7 died (day 4) after slow correction of hyponatremia. With slow correction, the rats lost $11 \pm 2 \%$ of body weight on day 1 and $6 \pm 2 \%$ on day 2 and then gradually regained body weight to nearly pretreatment values by day 7 . With rapid correction, the rats lost $10 \pm 3 \%$ of weight on day 1 and $7 \pm 3 \%$ on day 2. Most of them did not gain weight afterward and weighed $77 \pm 9 \%$ of pretreatment weight on day 7. Fig. $2 A$ shows the

Table IV. Effect of Chronic Hyponatremia on Brain Contents of Osmoles

\begin{tabular}{|c|c|c|c|c|}
\hline & \multicolumn{2}{|c|}{ NMR study } & \multicolumn{2}{|c|}{ HPLC study } \\
\hline & \multicolumn{4}{|c|}{ Rat group ( $n$ ) } \\
\hline & Control (6) & Hyponatremia (6) & Control (6) & Hyponatremia (6) \\
\hline & \multicolumn{4}{|c|}{$\mathrm{mmol} / \mathrm{kg} \mathrm{H}_{2} \mathrm{O}$} \\
\hline Myoinositol & $5.1 \pm 0.4$ & $2.1 \pm 0.6^{*}$ & $6.5 \pm 0.3$ & $3.2 \pm 0.2^{*}$ \\
\hline GPC & $1.1 \pm 0.2$ & $0.5 \pm 0.1^{*}$ & $1.3 \pm 0.3$ & $0.6 \pm 0.1^{*}$ \\
\hline $\mathrm{PCr} / \mathrm{Cr}$ & $3.5 \pm 0.2$ & $2.1 \pm 0.3^{*}$ & ND & ND \\
\hline Glutamate & $11.6 \pm 1.0$ & $6.1 \pm 0.9^{*}$ & ND & ND \\
\hline Glutamine & $4.0 \pm 0.3$ & $1.8 \pm 0.6^{*}$ & $3.8 \pm 0.3$ & $1.8 \pm 0.2^{*}$ \\
\hline Taurine & $3.5 \pm 0.4$ & $1.3 \pm 0.4^{*}$ & $4.4 \pm 0.6$ & $1.7 \pm 0.3^{*}$ \\
\hline Urea & ND & ND & $4.1 \pm 0.6$ & $3.4 \pm 0.3$ \\
\hline
\end{tabular}

$n$, Number of rats in each group. Values $\left(\mathrm{mmol} / \mathrm{kg} \mathrm{H}_{2} \mathrm{O}\right)$ are mean \pm SD. ${ }^{*} P<0.01$ vs. control rats. ND, Not detectable.

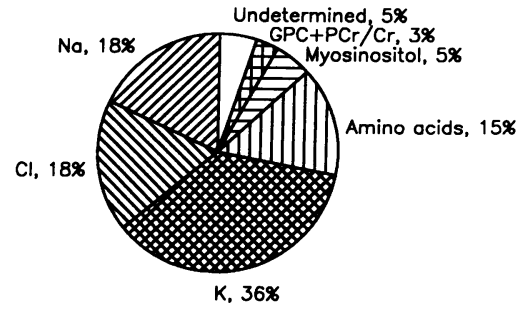

change of serum $\mathrm{Na}$ during the correction of hyponatremia. With rapid correction, serum $\mathrm{Na}$ increased from $109 \pm 4$ to $138 \pm 4 \mathrm{meq} / \mathrm{liter}$ within $24 \mathrm{~h}$. The serum $\mathrm{Na}$ decreased slightly to $135 \pm 3$ on day 2 and was found in normal range on day 7 (142 $\pm 3 \mathrm{meq} / \mathrm{liter})$. With slow correction, serum sodium increased from $111 \pm 5$ to $128 \pm 4 \mathrm{meq} /$ liter on day 1 and to $140 \pm 4$ $\mathrm{meq} / \mathrm{liter}$ on day 2 . The serum $\mathrm{Na}$ remained in the normal range thereafter. The changes in serum $\mathrm{Cl}$ concentration and osmolality paralleled the changes in serum $\mathrm{Na}$.

Brain water and electrolytes. Fig. $2 \mathrm{~B}$ demonstrates the time course of the changes in brain water content during the correction of chronic hyponatremia. With rapid correction, signifcant brain dehydration occurred on day 1 with brain water content falling to $77.4 \pm 0.3 \%$ of tissue weight compared with a normal value of $78.6 \pm 0.2 \%(P<0.01)$. The brain water content increased to $78.3 \pm 0.2 \%$ on day 2 and was $78.5 \pm 0.2 \%$ on day 7 . No brain dehydration was observed during slow correction of hyponatremia. The brain water content was $78.5 \pm 0.2 \%$ on day $1,78.4 \pm 0.2 \%$ on day 2 , and $78.5 \pm 0.2 \%$ on day 7 . Fig. $2, C$ and $D$ shows the time course of the changes in brain $\mathrm{Na}$ and $\mathrm{Cl}$ concentrations, respectively. With rapid correction, both brain $\mathrm{Na}$ and $\mathrm{Cl}$ increased to a level significantly above normal on day $1\left(\mathrm{Na} 65 \pm 3\right.$ vs. $56 \pm 2 \mathrm{meq} / \mathrm{kg} \mathrm{H}_{2} \mathrm{O} ; \mathrm{Cl} 52 \pm 2$ vs. $42 \pm 2 \mathrm{meq} /$ $\mathrm{kg} \mathrm{H}_{2} \mathrm{O}$, both $P<0.01$ ) and returned to normal by day 2 . With slow correction, brain sodium increased to $52 \pm 2 \mathrm{meq} / \mathrm{kg} \mathrm{H}_{2} \mathrm{O}$ on day $1(P<0.01$ vs. rapid correction) and to $57 \pm 2 \mathrm{meq} / \mathrm{kg}$ $\mathrm{H}_{2} \mathrm{O}$ on day 2 . Similarly, brain $\mathrm{Cl}$ increased to $38 \pm 2 \mathrm{meq} / \mathrm{kg}$ $\mathrm{H}_{2} \mathrm{O}$ on day 1 ( $P<0.01$ vs. rapid correction) and to $44 \pm 2$ $\mathrm{meq} / \mathrm{kg} \mathrm{H}_{2} \mathrm{O}$ on day 2 . Brain $\mathrm{K}$ increased more slowly with rapid correction compared with brain sodium $(111 \pm 2 \mathrm{meq} / \mathrm{kg}$ $\mathrm{H}_{2} \mathrm{O}$ on day $1,115 \pm 2 \mathrm{meq} / \mathrm{kg} \mathrm{H}_{2} \mathrm{O}$ on day 2 ). With slow correction, brain $\mathrm{K}$ reached a near normal level on day $2(107 \pm 2$ $\mathrm{meq} / \mathrm{kg} \mathrm{H} \mathrm{H}_{2} \mathrm{O}$ on day $1,116 \pm 2 \mathrm{meq} / \mathrm{kg} \mathrm{H} \mathrm{H}_{2} \mathrm{O}$ on day 2 ). Therefore, the change in brain $\mathrm{K}$ was parallel to the change of serum $\mathrm{Na}$ with slow correction. With rapid correction, normalization of brain $\mathrm{K}$ occurred $1 \mathrm{~d}$ after the correction of serum $\mathrm{Na}$.

Brain organic osmolytes. Table $\mathrm{V}$ shows the changes of brain organic osmolytes during the correction of hyponatremia. Brain urea level was determined by HPLC, and concentrations of other molecules were determined by ${ }^{1} \mathrm{H}-\mathrm{NMR}$ spectroscopy. Brain myoinositol concentration decreased on day 1 with either rapid $\left(1.2 \pm 0.2 \mathrm{mmol} / \mathrm{kg} \mathrm{H}_{2} \mathrm{O}\right)$ or slow $(1.1 \pm 0.2$ $\mathrm{mmol} / \mathrm{kg} \mathrm{H}_{2} \mathrm{O}$ ) correction of hyponatremia. The myoinositol concentration then increased to $2.2 \pm 0.3 \mathrm{mmol} / \mathrm{kg} \mathrm{H}_{2} \mathrm{O}$ on day 2 and achieved a normal value on day $7(5.3 \pm 0.4 \mathrm{mmol} / \mathrm{kg}$ $\mathrm{H}_{2} \mathrm{O}$ ) with slow correction. With rapid correction, brain myoinositol concentration increased and did not reach normal by day 7 (4.1 \pm 0.3 vs. $\left.5.1 \pm 0.4 \mathrm{mmol} / \mathrm{kg} \mathrm{H}_{2} \mathrm{O}, P<0.01\right)$. With rapid correction, brain GPC concentration reached the normal range on day $1\left(1.0 \pm 0.2 \mathrm{mmol} / \mathrm{kg} \mathrm{H}_{2} \mathrm{O}\right)$ and increased significantly above normal $\left(1.9 \pm 0.4\right.$ vs. $\left.1.1 \pm 0.2 \mathrm{mmol} / \mathrm{kg} \mathrm{H} \mathrm{H}_{2} \mathrm{O}\right)$ on 

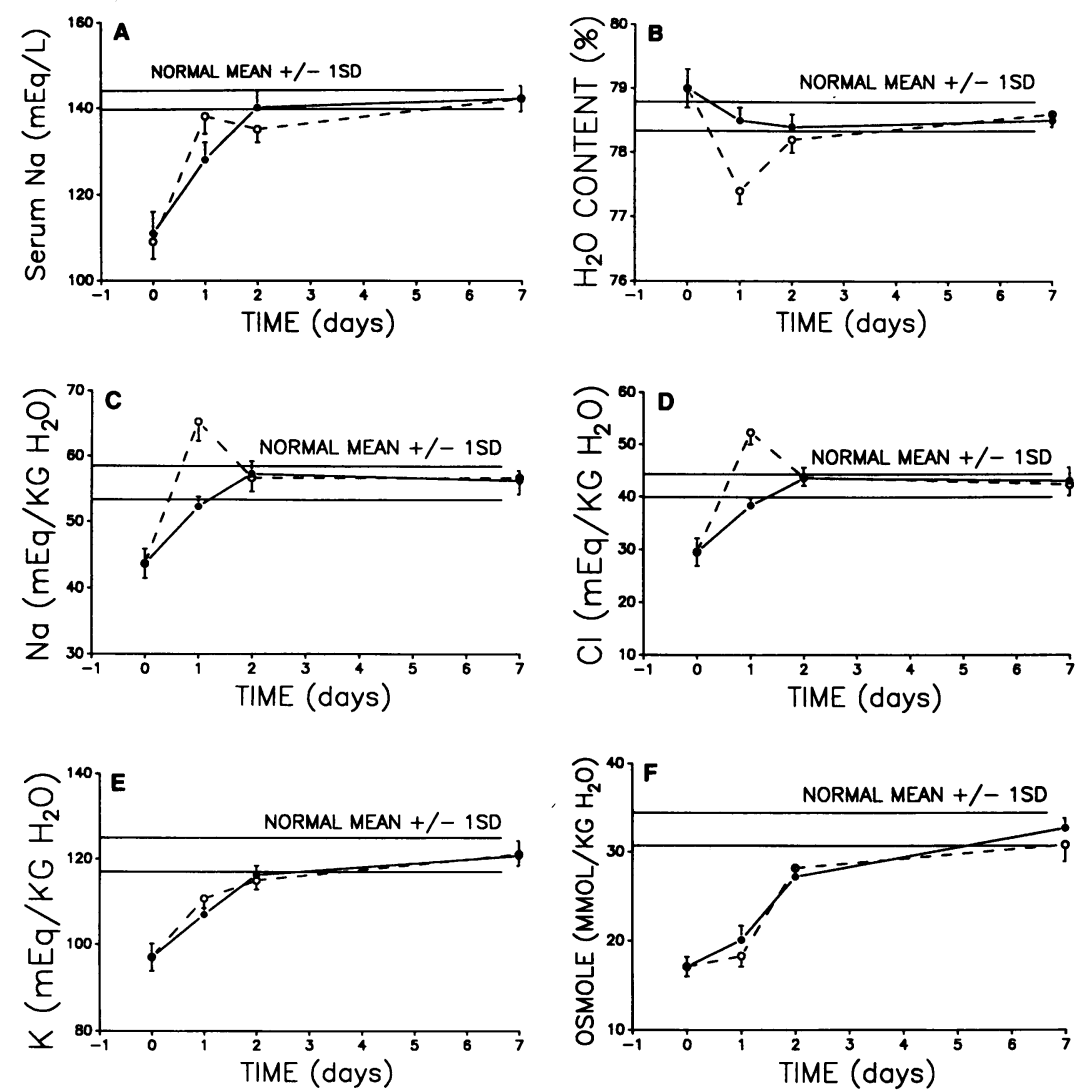

Figure 2. Time course of the change in serum sodium $(A)$, brain water content $(B)$, brain sodium $(C)$, chloride $(D)$, potassium $(E)$, and organic osmolytes $(F)$ during correction of chronic hyponatremia. Open circle indicates rapid correction, and closed circle indicates slow correction. The horizontal zone indicates the normal range of each parameters (normal mean \pm 1 $\mathrm{SD}$ ). On day 1 , serum $\mathrm{Na}$, brain water content, and brain $\mathrm{Na}$ and $\mathrm{Cl}$ concentrations of rats subjected to rapid correction were significantly different from those of rats with slow correction (all $P<0.01$ ). Brain $\mathrm{K}$ and organic osmolyte content were not different between the two groups.

day 7. With slow correction, brain GPC concentration increased to normal on day 1 and remained unchanged through day 7 . The changes in brain $\mathrm{PCr} / \mathrm{Cr}$ concentrations were similar with both rapid and slow correction. On day $2, \mathrm{PCr} / \mathrm{Cr}$ concentrations were still significantly below normal with both forms of correction (rapid correction $2.5 \pm 0.3 \mathrm{mmol} / \mathrm{kg} \mathrm{H}_{2} \mathrm{O}$; slow correction $2.4 \pm 0.3$ vs. $3.5 \pm 0.2 \mathrm{mmol} / \mathrm{kg} \mathrm{H}_{2} \mathrm{O}$, both $P$ $<0.01$ ). By day $7, \mathrm{PCr} / \mathrm{Cr}$ concentrations were normal with both forms of correction. Brain concentrations of major amino acid osmolytes including glutamate, glutamine, and taurine also increased gradually after the correction of hyponatremia. With rapid correction, glutamate, glutamine, and taurine were
$7.6 \pm 0.9,2.4 \pm 0.4$, and $1.0 \pm 0.2 \mathrm{mmol} / \mathrm{kg} \mathrm{H}_{2} \mathrm{O}$, respectively (all $P<0.01$ compared with control), on day 1 , and $11.2 \pm 0.9$ ( $P$ $=\mathrm{NS}), 3.0 \pm 0.2(P<0.01), 2.1 \pm 0.3 \mathrm{mmol} / \mathrm{kg} \mathrm{H}_{2} \mathrm{O}(P<0.01)$, respectively, on day 2 . The brain concentrations of these amino acids were all within the normal range on day 7 . With slow correction, glutamate, glutamine, and taurine concentrations were $7.6 \pm 1.2,2.8 \pm 0.3$, and $1.2 \pm 0.2 \mathrm{mmol} / \mathrm{kg} \mathrm{H}_{2} \mathrm{O}$ (all $P$ $<0.01$ compared with control) on day 1 , and $9.8 \pm 0.6,3.1 \pm 0.4$, and $1.5 \pm 0.3 \mathrm{mmol} / \mathrm{kg} \mathrm{H}_{2} \mathrm{O}$ (all $P<0.01$ ), respectively, on day 2. The concentrations of these amino acids were also within the normal range on day 7 . Brain urea concentration remained unchanged with rapid correction. However, with slow correc-

Table V. Brain Contents of Osmoles during the Correction of Hyponatremia

\begin{tabular}{|c|c|c|c|c|c|c|}
\hline \multirow[b]{2}{*}{ Days } & \multicolumn{3}{|c|}{ Rapid correction } & \multicolumn{3}{|c|}{ Slow correction } \\
\hline & 1 & 2 & 7 & 1 & 2 & 7 \\
\hline & \multicolumn{6}{|c|}{$\mathrm{mmol} / \mathrm{kg} \mathrm{H} \mathrm{H}_{2} \mathrm{O}$} \\
\hline Myoinositol & $1.2 \pm 0.2^{*}$ & $2.4 \pm 0.4^{*}$ & $4.1 \pm 0.3^{*}$ & $1.1 \pm 0.2^{*}$ & $2.2 \pm 0.3^{*}$ & $5.3 \pm 0.4$ \\
\hline GPC & $1.0 \pm 0.2$ & $1.2 \pm 0.6$ & $1.9 \pm 0.4^{*}$ & $0.9 \pm 0.1$ & $1.1 \pm 0.3$ & $1.3 \pm 0.4$ \\
\hline $\mathrm{PCr} / \mathrm{Cr}$ & $1.9 \pm 0.1^{*}$ & $2.5 \pm 0.3^{*}$ & $3.4 \pm 0.3$ & $2.1 \pm 0.2^{*}$ & $2.4 \pm 0.3^{*}$ & $3.6 \pm 0.3$ \\
\hline Glutamate & $7.6 \pm 0.9^{*}$ & $11.2 \pm 0.9$ & $11.0 \pm 0.7$ & $7.6 \pm 1.2^{*}$ & $9.8 \pm 0.6^{*}$ & $11.9 \pm 0.6$ \\
\hline Glutamine & $2.4 \pm 0.4^{*}$ & $3.0 \pm 0.2^{*}$ & $3.6 \pm 0.5$ & $2.8 \pm 0.3^{*}$ & $3.1 \pm 0.4^{*}$ & $3.5 \pm 0.3$ \\
\hline Taurine & $1.0 \pm 0.2^{*}$ & $2.1 \pm 0.3^{*}$ & $3.0 \pm 0.4$ & $1.2 \pm 0.2^{*}$ & $1.5 \pm 0.3^{*}$ & $3.6 \pm 0.3$ \\
\hline Urea & $3.5 \pm 0.6$ & $3.8 \pm 0.4$ & $4.1 \pm 0.3$ & $4.5 \pm 0.2$ & $5.3 \pm 0.5^{*}$ & $3.7 \pm 0.3$ \\
\hline Total & $18.6 \pm 1.2^{*}$ & $26.2 \pm 1.0^{*}$ & $31.1 \pm 1.9$ & $20.2 \pm 1.6^{*}$ & $25.4 \pm 1.2^{*}$ & $33.3 \pm 1.4$ \\
\hline
\end{tabular}

Six rats in each group. Values $\left(\mathrm{mmol} / \mathrm{kg} \mathrm{H}_{2} \mathrm{O}\right)$ are mean $\pm \mathrm{SD} .{ }^{*} P<0.01$ vs. control rats. 
tion, the brain urea content increased significantly to $5.3 \pm 0.5$ (vs. control $4.1 \pm 0.6 \mathrm{mmol} / \mathrm{kg} \mathrm{H} \mathrm{H}_{2} \mathrm{O}, P<0.05$ ) on day 2 . The brain urea concentrations decreased when dehydration was stopped and were normal range on day 7 .

Fig. 3 demonstrates the contributions of both electrolytes and organic osmolytes to total brain osmolality in control rats, hyponatremic rats, and rats subjected to both rapid and slow correction at the time of normalization of serum $\mathrm{Na}$. In control rats, the ratio of the sum of tissue ion concentrations to the sum of tissue organic osmolyte concentrations was $6.8 \pm 0.2$. In hyponatremic rats, both electrolytes and osmolytes decreased significantly as described earlier. The ion/osmolyte ratio rose to $10.1 \pm 0.5$ ( $P<0.01$ vs. control). As serum sodium returned to normal, the sum of electrolytes and osmolytes also reached normal in both groups of correction. However, with rapid correction, the increase of osmolality was mainly due to $\mathrm{Na}$ and $\mathrm{Cl}$ concentrations which are significantly above normal. The ion/ osmolyte ratio was found to increase to $12.5 \pm 1.0$ with rapid correction $(P<0.01$ vs. control). With slow correction, both ions and osmolytes increased with an ion/osmolyte ratio of $8.0 \pm 0.4$ ( $P<0.05$ vs. control; $P<0.01$ vs. rapid correction group).

\section{Discussion}

In this study we investigated the effects of induction and correction of chronic hyponatremia on brain water, electrolytes, and organic osmolytes in rats. Clinical and experimental observations have suggested that rapid correction of severe chronic hyponatremia (serum $\mathrm{Na}<120 \mathrm{meq} / \mathrm{liter}$ ) is associated with the development of central pontine myelinolysis (13-18). Verbalis and Drutarosky have demonstrated that chronic hyponatremia induced by the combination of minipump infusion of DDAVP and feeding of a liquid diet is well tolerated by rats (20). When the rats with chronic hyponatremia were treated with hypertonic solution, serum $\mathrm{Na}$ was corrected to the normal range within $24 \mathrm{~h}$, and $90 \%$ of the rats developed demyelinative lesions (24). In our study, using the same animal model developed by Verbalis and Drutarosky, we were able to examine the roles of the changes in brain electrolyte and organic osmolyte concentrations on the pathogenesis of central pontine myelinolysis.

With $3 \mathrm{~d}$ of treatment with DDAVP infusion and feeding of a liquid diet, all rats developed profound hyponatremia (serum sodium $109 \pm 3 \mathrm{meq} / \mathrm{liter}$ ). The brain water content of the hyponatremic rats was not significantly different from the control rats, demonstrating adaptation to this insult. Specifically, brain

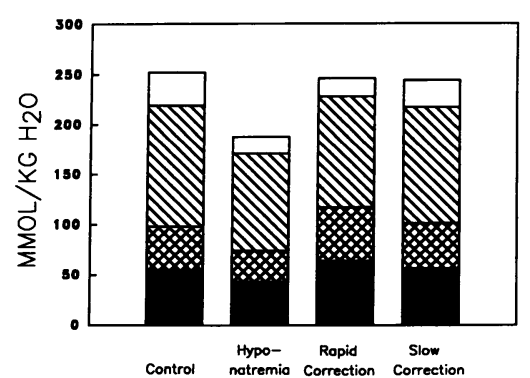

Figure 3. Effect on brain solutes of chronic hyponatremia ( $3 \mathrm{~d}$, serum $\mathrm{Na} 109 \pm 3 \mathrm{meq} / \mathrm{liter}$ ) and correction of hyponatremia. Brain solutes were determined at $24 \mathrm{~h}$ of rapid correction (serum Na $138 \pm 4 \mathrm{meq} /$ liter) and $48 \mathrm{~h}$ of slow correction (serum Na $140 \pm 4 \mathrm{meq} / \mathrm{liter})$. Solid area indicates $\mathrm{Na}$; criss-cross area, $\mathrm{Cl}$; shaded area, $\mathrm{K}$; and blank area, total organic osmolytes. electrolyte concentrations were significantly reduced with chronic hyponatremia. The contributions of the loss of $\mathrm{Na}, \mathrm{K}$, and $\mathrm{Cl}$ to the total decrease in brain osmolality were: $\mathrm{Na}, 18 \%$; $\mathrm{K}, 36 \%$; and $\mathrm{Cl}, 18 \%$ (Fig. 1). The decreases in brain electrolyte concentrations in response to hyponatremia has been well documented (19-21, 25-28), and our results were quite consistent with these previous reports in which the contribution of electrolytes to the observed changes in osmolality during hyponatremia ranges from 61 to $74 \%(20,21,25-28)$. Organic osmolytes also decreased significantly and contributed $\sim 23 \%$ of the total decrease of brain osmolality in our study. The decrease of individual organic osmolytes ranged from 40 to $63 \%$. Thurston and co-workers studying weanling mice with sustained hyponatremia observed that decreases in brain amino acid concentrations accounted for $25 \%$ of the observed decreases in brain osmolality $(9,19)$. In our study, we measured only glutamate, glutamine, and taurine concentrations and found that the contribution of the changes in concentrations of these amino acids accounted for $15 \%$ of the observed decrease in osmolality. It is likely that the major part of the undetermined molecules in Fig. 1, which amounts to $5 \%$ of the total change in osmolality, can be accounted for by changes in the concentrations of amino acids that we did not measure. The use of different species, ages of animals, and experimental models probably accounts for the small remaining discrepancy. This $5 \%$ of osmotically-active particles, which are not accounted for in this study, might also be unmeasured ions or other non-amino acid organic osmolytes.

From our results, we can estimate the contributions of electrolytes and organic osmoles to the osmolality changes in the intracellular and extracellular fluid. Holliday et al. (21) have found that the contribution of extracellular volume was unchanged in the brain of rats with chronic hyponatremia $(3 \mathrm{~d})$ by measuring chloride space. In this study, the brain water content of hyponatremic rats was not significantly different from controls. Therefore, we assume that the contribution of the extracellular volume in hyponatremic rats is the same as that in control, i.e., $\sim 20 \%$ as estimated by van Harreveld (29). In this compartment, the decreases in $\mathrm{Na}$ and $\mathrm{Cl}$ concentrations can account for most of the observed decrease in osmolality. Therefore, the contribution of changes in intracellular solute concentrations to the change in intracellular osmolality can be estimated as follows: sodium, $10 \%$; chloride, $10 \%$; potassium, $45 \%$; and organic osmolytes, $35 \%$ (assuming the undetermined fraction is also organic osmolytes as discussed above).

The effects of rapid and slow correction of hyponatremia on brain water and electrolytes were different. Rapid correction, but not slow correction, was associated with brain dehydration and a transient overshoot of brain $\mathrm{Na}$ and $\mathrm{Cl}$ concentrations. Brain dehydration after rapid correction has been observed previously. It occurs because of inadequate reaccumulation and resynthesis of intracellular electrolytes and organic osmolytes after a rapid rise in extracellular osmolality. Sterns et al. also noted the overshoot of brain sodium after correcting serum sodium from 98 to $129 \mathrm{meq} / \mathrm{liter}$ in $9 \mathrm{~h}$. The brain sodium content became $10 \%$ higher than controls in their study (28). In our rapid correction group, serum $\mathrm{Na}$ was corrected to normal within $24 \mathrm{~h}$. Brain $\mathrm{Na}$ and $\mathrm{Cl}$ became 16 and $24 \%$ higher than control, respectively. On the other hand, brain $\mathrm{K}$ recovered more slowly than brain $\mathrm{Na}$. With this rapid correction, brain $\mathrm{K}$ was still $8 \%$ lower than controls when serum $\mathrm{Na}$ was corrected to the normal range. Similar results 
were reported by other groups $(25,28)$. This overshoot of brain $\mathrm{Na}$ and $\mathrm{Cl}$ is probably due to the bulk flow of cerebrospinal fluid into the brain in response to acute rising of serum osmolarity. Cserr et al. have shown that the gain of $\mathrm{Na}$ and $\mathrm{Cl}$ after elevation of plasma osmolality is mainly from the CSF influx, while plasma is the source of volume regulatory gain of $\mathrm{K}(30$, 31). The $\mathrm{Na}$ from the cerebrospinal fluid diffuses into the interstitial fluid and then enters the cell through a Na${ }^{+} / \mathrm{H}^{+}$exchange system. Adler and Simplaceanu have shown that the brain $\mathrm{pH}$ of hyponatremic rats $(2 \mathrm{~d})$ was increased from 7.09 to 7.18 when plasma sodium was corrected from 122 to $146 \mathrm{meq} / \mathrm{liter}$ (32). It is likely that the rise of serum $\mathrm{Na}$ activates the $\mathrm{Na}-\mathrm{H}$ antiporter, therefore, causing an increased intracellular $\mathrm{Na}$ and decreased intracellular proton content. A similar phenomenon has been observed in many cell culture systems such as in glial cells (33) and lymphocytes (34).

Most of the brain organic osmolytes recovered slowly in response to correction of hyponatremia. Brain GPC and glutamate concentrations, however, recovered more quickly. Brain GPC concentrations returned to the normal range on day 1 in both rapid and slow correction groups. Glutamate concentrations returned to normal on day 2 with rapid correction and approached normal range on day 2 with slow correction. The other brain organic osmolytes did not reach normal concentrations on day 2 in either experimental group. Myoinositol and taurine concentrations, in fact, decreased on the first day of correction and, only then, started to increase in both experimental groups. It appears that brain cells regulate the intracellular concentrations of organic osmolytes quite differently. The study of the cellular mechanisms involved in the regulation of these organic osmolyte concentrations will be an important area for further investigation.

When adding all the measured osmolytes together, as shown in Fig. $2 F$, the rate of reaccumulation of osmolytes is not different between the groups with rapid and slow correction. On day 7 , all osmolytes return the normal range in the group with slow correction. However, in the group with rapid correction, brain concentrations of myoinositol is lower and GPC is higher than controls at this time. We are not able to explain these changes at present. The changes of brain osmolyte concentrations during the correction of hyponatremia in rats which we observed, were, in general, quite similar to those observed in hyponatremic weanling mice subjected to a similar treatment in the study by Thurston et al. (19). However, we noted in our study that the increases in brain glutamate concentrations during correction was much slower than that observed by Thurston et al. in weanling mice. Again, species difference, age of the animals, and differences in experimental model can account for this discrepancy.

The results of our study may offer insight into the potential injury associated with rapid correction of hyponatremia. This insight is, perhaps, best illustrated in Fig. 3 which demonstrates the contributions of both electrolytes and organic osmolytes to total brain osmolality in rats subjected to both rapid and slow correction at the time of normalization of serum $\mathrm{Na}$. The ratio of the sum of tissue ion concentrations to the sum of tissue organic osmolyte concentrations was 6.8 in control rats. This ratio was found to increase to 12.5 with rapid correction but only 8.0 with slow correction. High ionic strength may be detrimental to cells by a variety of mechanisms including effects on protein-protein and protein-substrate interactions $(1,2)$. Yancey and Burg (35), and Yancey et al. (36) showed that a hyper- osmolar medium inhibited cell growth and survival of a renal epithelial cell line measured as colony-forming efficiency. The addition of organic osmolytes, such as betaine, restored the colony-forming efficiency, while the inhibition of sorbitol (a renal osmolyte) synthesis reduced colony-forming efficiency. These experiments demonstrate that osmolytes have significant protective effects against osmotic stress in cultured mammalian cells. The protective effect of osmolytes has also been shown in animal studies. Trachtman et al. reported that taurine depletion rendered kittens more susceptible to chronic hypernatremia judging by higher mortality and seizure activity and lower brain water content compared with controls (37). Although in our studies, histological examinations of the brain was not performed, previous studies have clearly demonstrated that rapid correction of chronic hyponatremia to normonatremic or hypernatremic levels causes demyelinated lesion in basal ganglia, internal capsule, cerebellum, corpus striatum, brainstem tegmentum, and other areas in the rats $(15,17)$, rabbits (18), and dogs (16). More recently, Verbalis and Martinez (24) have demonstrated that demyelination lesions could be found in $90 \%$ of rats that received hypertonic saline infusion for rapid correction of hyponatremia, but only $5 \%$ in rats treated with water restriction. The methods of induction and correction of hyponatremia as well as the degree of hyponatremia and rate of correction in this study are quite similar to those described by Verbalis and Martinez. Therefore, the observations in this study that the high cerebral ion concentrations achieved without adequate protection from organic osmolytes during rapid correction of hyponatremia, may be relevant to the development of osmotic demyelination of the brain reported by previous investigators. However, the brain is a heterogeneous organ with many different anatomic compartments and individual cell types. Why certain areas and certain cell types, such as oligodendrocytes, are more susceptible to the rapid increase of osmolality is not clear and is currently under investigation in our laboratory.

In summary, this investigation established that most of the change of brain osmolality in chronic hyponatremia can be accounted by the changes in organic osmolytes and brain electrolytes; and rapid correction of hyponatremia is associated with an overshoot of brain $\mathrm{Na}$ and $\mathrm{Cl}$ levels along with a low organic osmolyte level. The high ion to organic osmolyte ratio achieved with rapid correction of hyponatremia suggests that brain cells could be subjected to ion-induced injury without adequate protection from organic osmolytes. Whether these electrolyte and organic osmolyte changes play a role in the pathogenesis of central pontine myelinolysis remains to be determined.

\section{Acknowledgments}

Dr. Y. H. Lien is supported by a National Kidney Foundation, Burroughs Wellcome Corp. Fellowship Award. Dr. J. I. Shapiro is supported by an American Heart Association, Squibb Corp. Clinician Scientist Award.

\section{References}

1. Yancey, P. H., M. E. Clark, S. C. Hand, R. D. Bowlus, and G. N. Somero. 1982. Living with water stress: evolution of osmolyte systems. Science (Wash. DC). 217:1214-1222.

2. Somero, G. N. 1986. Protons, osmolytes, and fitness of internal milieu for protein function. Am. J. Physiol. 251:R197-R213. 
3. Lockwood, A. H. 1975. Acute and chronic hyperosmolality. Arch. Neurol. 32:62-64.

4. Arieff, A. I., R. Guisado, and V. C. Lazarowitz. 1979. Pathology of hyperosmolar states. In Disturbances in Body Fluid Osmolarity. T. E. Andreoli, J. J. Grantham, and F. C. Rector, Jr., editors. American Physiology Society, Bethesda, MD. 227-250.

5. Thurston, J. H., R. E. Hauhart, and J. A. Dirgo. 1980. Taurine: a role in osmotic regulation of mammalian brain and possible clinical significance. Life Sci. 26:1561-1568.

6. Lien, Y.-H. H., J. I. Shapiro, and L. Chan. 1990. Effects of hypernatremia on organic brain osmoles. J. Clin. Invest. 85:1427-1435.

7. Heilig, C. W., M. E. Stromski, J. D. Blumenfeld, J. P. Lee, and S. R. Gullans. 1989. Characterization of the major brain osmolytes which accumulate in salt loaded rats. Am. J. Physiol. 257:F1108-F1116.

8. Lohr, J. W., J. McReynolds, T. Grimaldi, and M. Acara. 1988. Effect of acute and chronic hypernatremia on myoinositol and sorbitol concentration in rat brain and kidney. Life Sci. 43:271-276.

9. Thurston, J. H., W. R. Sherman, R. E. Hauhart, and R. F. Kloepper. 1989. Myo-inositol: a newly identified nonnitrogenous osmoregulatory molecule in mammalian brain. 1989. Pediatr. Res. 26:482-485.

10. Adams, R. D., M. Victor, and E. L. Mancall. 1959. Central pontine myelinolysis: a hitherto undescribed disease occurring in alcoholic and malnourished patients. Arch. Neurol. Psychiatry 81:154-172.

11. McCormick, W. F., and C. M. Danneel. 1967. Central pontine myelinolysis. Arch. Intern. Med. 119:444-478.

12. Wright, D. G., R. Laureno, and M. Victor. 1979. Pontine and extrapontine myelinolysis. Brain. 102:361-385.

13. Sterns, R. H. 1987. Severe symptomatic hyponatremia: treatment and outcome. A study of 64 cases. Ann. Intern. Med. 107:656-664.

14. Norenberg, M. D., K. O. Leslie, and A. S. Robertson. 1982. Association between rise in serum sodium and central pontine myelinolysis. Ann. Neurol. 11:128-137.

15. Kleinschmidt-Demasters, B. K., and M. D. Norenberg. 1981. Rapid correction of hyponatremia causes demyelination: relation to central pontine myelinolysis. Science (Wash. DC). 211:1068-1070.

16. Laureno, R. 1983. Central pontine myelinolysis following rapid correction of hyponatremia. Ann. Neurol. 13:232-242.

17. Ayus, J. C., R. K. Krothapalli, and D. L. Armstrong. 1985. Rapid correction of severe hyponatremia in the rat: histopathological changes in the brain. Am. J. Physiol. 248:F711-719.

18. Illowsky, B., and R. Laureno. 1987. Encephalopathy and myelinolysis after rapid correction of hyponatremia. Brain. 110:855-867.

19. Thurston, J. H., and R. E. Hauhart. 1987. Brain amino acids decrease in chronic hyponatremia and rapid correction causes brain dehydration: possible clinical significance. Life Sci. 40:2539-2542.

20. Verbalis, J. G., and M. D. Drutarosky. 1988. Adaptation to chronic hypoosmolarity in rats. Kidney Int. 34:351-360.
21. Holliday, M. A., M. N. Kalayci, and J. Harrah. 1968. Factors that limit brain volume in response to acute and sustained hyper- and hyponatremia. $J$. Clin. Invest. 47:1916-1928.

22. Wolff, S. D., P. H. Yancey, T. S. Stanton, and R. S. Balaban. 1989. A simple HPLC method for quantitating major organic solutes of renal medulla. Am. J. Physiol 256:F954-F956.

23. Wallerstein, S., C. I. Zucker, and J. L. Fleiss. 1980. Some statistical methods useful in circulation research. Circ. Res. 47:1-9.

24. Verbalis, J. G., and A. J. Martinez. 1989. Osmotic demyelination is dependent on both rate and magnitude of correction of chronic hyponatremia in rats. Clin. Res. 37:586a. (Abstr.)

25. Dila, C. J., and H. M. Pappius. 1972. Cerebral water and electrolytes: an experimental model of inappropriate secretion of antidiuretic hormone. Arch. Neurol. 26:85-90.

26. Rymer, M. M., and R. A. Fishman. 1973. Protective adaptation of brain to water intoxication. Arch. Neurol. 28:49-54.

27. Arieff, A. I., F. Llach, and S. G. Massry. 1976. Neurological manifestations and morbidity in hyponatremia: correlation with brain water and electrolytes. Medicine (Baltimore). 55:121-129.

28. Sterns, R. H., D. J. Thomas, and R. M. Herndon. 1989. Brain dehydration and neurologic deterioration after rapid correction of hyponatremia. Kidney Int. 35:69-75.

29. Van Harreveld, A. 1972. The extracellular space in the vertebrate centra nervous system. In The structure and function of nervous tissue. G. H. Bourne, editor. Academic Press, New York. 449-511.

30. Cserr, H. F., M. DePasquale, and C. S. Patlak. 1987. Volume regulation influx of electrolytes from plasma to brain during acute hyperosmolality. Am. J. Physiol. 253:F530-F537.

31. Pullen, R. G. L., M. Depasquale, and H. F. Cserr. 1987. Bulk flow of cerebrospinal fluid into brain in response to acute hyperosmolality. Am. J. Physiol. 253:F538-545.

32. Adler, S., and V. Simplaceanu. 1989. Effect of acute hyponatremia on rat brain $\mathrm{pH}$ and rat brain buffering. Am. J. Physiol. 256:F113-119.

33. Jean, T., C. Frelin, P. Vigne, and M. Lazdunski. 1986. The $\mathrm{Na}^{+} / \mathrm{H}^{+}$exchange system in glial cell lines. Properties and activation by a hyperosmolar shock. Eur. J. Biochem. 160:211-219.

34. Grinstein, S., C. A. Clarke, and A. Rothstein. 1983. Activation of $\mathrm{Na}^{+} / \mathrm{H}^{+}$ exchange in lymphocytes by osmotically induced volume changes and by cytoplasmic acidification. J. Gen. Physiol. 82:619-638.

35. Yancey, P. H., and M. B. Burg. 1990. Counteracting effects of urea and betaine in mammalian cells in culture. Am. J. Physiol. 258:R198-204.

36. Yancey, P. H., M. B. Burg, and S. M. Bagnasco. Effect of $\mathrm{NaCl}$, glucose, and aldose reductase on cloning efficiency of renal medullary cells. Am. J. Physiol. 258:C156-C163.

37. Trachtman, H., R. Barbour, J. A. Sturman, and L. Finberg. 1988. Taurine and osmoregulation: taurine is a cerebral osmoprotective molecule in chronic hypernatremic dehydration. Pediatr. Res. 23:35-39. 